\title{
IMPERFECTIONS OF FINANCIAL EDUCATION FOR AN ADEQUATE COMPREHENSION OF THE NATIONAL FISCAL POLICY
}

\author{
Prof. Dr. Gediminas Dubauskas
}

General Jonas Žemaitis Military Academy of Lithuania,

\begin{abstract}
Educating on the revenue enhancement system in state-supported finance is likely an essential issue for the country's development. This content changes public sector and the sustainability of citizens' lives; therefore, a significant focus on the broad improvement of finance studies is essential. Furthermore, the activity could be organized in connection with the applicable higher education programs. On the other hand, financial management education is treated differently in different countries. It is becoming increasingly important that such a discussion does not directly benefit common development of financial education in recent years. One of the possible ways to deal with personal finances in different economic conditions could be changing students' attitude to finance knowledge at universities. Young people could be supported by financial education programs that are clearly incorporated into their undergraduate or postgraduate courses. The correct management of these programs helps to improve students and cadets learning experience and the economic wellbeing. Moreover, the learning based on public administration and public finance probably educates patriots of the country and people intolerant to non-transparent activities of public servants. Eventually, the best way to determine the country's consolidated tax paid by natural and legal persons could be the tax burden rate. Likewise, the financial data supplied to the main European statistics authority by national statistical institutions sometimes can be slightly incorrect. Therefore, even more important issue could be an ordinary citizen living only from the income related to labour relations (or corresponding relations of income) and having an obviously higher tax burden.

Another crucial task of the paper is to reveal how taxation, public debt and spending and fiscal policy are perceived by the citizens. In addition, it also tries to respond to questioning about the financial and economic importance on financial education. Furthermore, the theoretical task of the paper is to show the size of the government debt, its service and expenditure in Lithuania and Latvia during the last crisis in 2008. Therefore, it is possible to consider the increase of direct taxes burden by almost twice comparing to the formally announced country's tax burden. However, additional tax burden includes hidden taxes related to the aggregated spending of an individuals' income. In an average case, the tax burden for an ordinary employee could come near to two-thirds of the gross yearly income. Then, the overpaid debt services can be very sensitive given to the assumption that an ordinary worker has an approximately adequate level of financial and economic education. The perception of tax burden can encourage each citizen of the country to be responsible for all public servant activities and budget planning processes. Public revenue enhancement is often difficult due to the use of the same concept of taxes as fixed costs for public sector
\end{abstract}


when a person directly receives nothing but additional payments for the majority of public sector services. Therefore, the confusion of terms is fairly constant, which once again shows the need for public finances literacy in all areas of study programs for students or cadets. An authorized Lithuania's tax burden has comprised less than thirty percent of the country's nominal gross domestic product in recent years. Nevertheless, political leaders and socalled experts suggest the necessity for increasing Lithuania's accumulated tax burden. However, there may be a fundamental mistake that social insurance and compulsory health insurance contributions to the funds are not calculated into private individuals and legal entities tax burden. Fortunately, the last year's budget considered social payments as part of tax revenues. Unfortunately, there are diminutive amount of signs in the continuity of Lithuania's fiscal policy in the 21 st century.

Keywords: management, government debt, taxation, budget, economic sustainability

\section{Introduction}

Finance and public money management have a historical concept of educational process and is one of the key economic and financial preparations in contemporary education. Money subject is possible with a number of complex aspects both permanent change in the market economy and historical origin of money and monetary politics. Why such knowledge is necessary for the first cycle university education? Financial education is relevant to each university undergraduate program. Incidentally, budget terminology and personal income taxation are known only from the employment relationships or labour relations or comparable to labour relations income.

The purpose of the paper is to reveal the importance of financial management to cadets and students, including public perception of administration and financial aspects of public revenues' mismanagement related to tax burden.

The object of the research is the financial (and partly economic) conceptualization of the cadets of General Jonas Žemaitis Military Academy of Lithuania and other students of higher education institutions of public finance and mismanagement of public expenditure and procurement in addition to the taxation burden concept.

The objectives of the paper are as follows: to review financial and public finance development in the contemporary scientific literature and to display a necessity for cadets and students' education of public finance and public expenditure management.

One of the key tasks of the paper is to reveal how taxation, public spending and fiscal policy are perceived by the citizens. In addition, it also attempts to answer the questions about financial and economic importance on financial education. Furthermore, the theoretical task of the paper is to show the size of government debt service and expenditure in Lithuania and Latvia during the last crisis.

The research methods and methodological analysis used in the research were 
formal investigation and qualitative and quantitative research methods; the data was taken from the Lithuanian, Latvian and EU financial institutions. The modification of full-time and part-time students and cadets were used for informal surveys. It is noteworthy that the data were collected from teaching public finance management, studies and educational textbooks collected by the author for a long period of time.

The continuity and sustainability of public finances is presently a sensitive topic in the economic policy discussion. It is because of the remainder of former debt crises in Europe and the long-term public spending pressures caused by the obstructive demographic change in the developed countries. This paper analyses some of the conceptualizations that were used to evaluate the continuity of public finance in Lithuania. Also, hypothetical criteria for sustainability are examined. The article is partly conducted by a literature compartmentalization mode. There is no consensus among economic experts about the accurate theoretical standard for public finance continuity and, in particular, sustainability. Preferably, each conceptualization to evaluate continuity and sustainability introduces its personal, sometimes different, definitions. This study examines the strengths and weaknesses of each approach and conditionally compares them. It was found that each formulation has its functions. The approaches should be viewed as additive. The accessibility of data and modelling resources, destinations of the analysis and other case-specific restrictions impact relative quality of the approaches in various situations. Nowadays, continuity and sustainability of public finances is a welltimed theme in many modern countries. Uncertainty has been raised by several reviewers and analysts of state-supported finances in the Western countries where these finances are in a sustainable development shape. After the financial crisis of the first decade in the twenty first century, public debts of many countries were on a sharp ascending route due to the enforcement of various input and activity accumulation directed to financial field and the entire economic system. Increasing liabilities integrated with long-term subjects similar to the sociological layer modification influence the symmetry between the people in the labour force and the number of retired persons. The changes advised fiscal agenda to study these cognitive factors sincere. Regrettably, there is a small indefinite quantity of signs in the continuity of Lithuanian fiscal policy.

The historical understanding of financial theories and realistic conception of educational process is one of the most important topics in economics and financial literacy across various countries. Nevertheless, it is not common that study programs are free of charge for university students. Therefore, the first financial impact on the majority of studies probably is the payment for education. The topic of cash has all possible complex aspects as a permanent change in the market economy and monetary policy considerations. The extent of knowledge required for higher university education is a permanent question. Therefore, it can be argued that it is essential to study the mentioned topics in the majority of study programs.

The municipal or local public authorities are the primary boundaries for citizens 
in everyday relations with the tax payers from these municipalities. Theoretically, public servants are constantly trying to increase their tax base and invoice roughly everything for their services that are expected to be free of charge (i.e. revenue improvement is already collected for the taxpayers). In this study, we discuss the Lithuanian and Latvian debt management. Regrettably, there are analogous cases in the majority of the post-authoritarian countries. From the transparency point of view, expenditures of the local authorities must be accessible to all taxpayers, including detailed components and, possibly, with comments about the expediency of using the exact tax. Unlike state budget legislation, local governments could be considered as a family that is not partially insulated from these observations about daily expenses and their municipal costs must be affordable. Municipal spending gives a theoretical examination for balancing the two key issues, increase the tax base, create new jobs and maintain the quality of life of the municipal community. Unfortunately, this concept is poorly understood in the post-undemocratic countries both by the public servants and taxpayers.

\section{Financial Security and Finance Curriculum in Educational Institutions}

There are many misconceptions about the importance of financial education programs at higher education and other institutions. It is especially important for public finances to understand their publicity. During totalitarian times, public finances were called "state finances" because the understanding of tax burden was a secondary topic to the dominating idea to create "a worldwide or at least nationwide socialism". Unfortunately, often these provisions remain in perception of some public servants and even in the concepts of new generation. At the same time, typical country's economic, financial and administrative problems are almost always associated with corruption and non-transparent situations in the public sector. Thus, as it was mentioned, these situations are probably the most common events in public finance management. Therefore, finance and especially public finance literacy could be one of the keys to solve corruption perception.

In general, the concept of public finances in the education process starts with tax and budget. The municipal tax revenues and budget structure can be presented as a good example of public finance functioning and should be the pattern to each citizen. On the other hand, the approach could be more suitable for the second- or third-year students in part-time studies or in postgraduate programs. The majority of students come directly from secondary schools to undergraduate or postgraduate study programs and usually are not familiar with self-living and self-paying practice. Even more complicated is the understanding of the state and national budgets or theoretical private enterprise finance. However, financing them from the revenues of taxable and non-taxable inflows in terms of financial education is more or less significant. At the same time, a person begins to understand the role of the state (and municipalities) in the economy and thus materializes the admission to the 
state economic regulation functions as a redistribution function, social function and control function. Financial education is also important to expanding the knowledge of the state and local government revenue and expenditure structure and basic laws providing the framework for tax collection and allocation of assignations.

Tax perception is frequently challenging. Since using the same concept of taxes and fees for public sector directly received nothing and charges for specific services (Brammer 2017); therefore, the confusion of terms is fairly constant, which once again shows the need for public finance literacy in all the areas of study programs for students or cadets. The authorized Lithuanian tax burden has comprised less than thirty percent of the country's nominal gross domestic product in the recent years. Nevertheless, political leaders and so-called experts permanently suggest the necessity of increasing Lithuania's accumulated tax burden. However, there may be a fundamental mistake that social insurance contributions and compulsory health insurance contributions to the funds are not calculated into private individuals and legal entities' tax burden. Fortunately, the last year's budget already considered social payments as part of tax revenues.

\section{Management of National Debt during Financial Crisis in the Baltic States}

The continuity and sustainability of public finance management could be represented by the example of public debt policy in Lithuania and Latvia during the crisis in the period of 2008-2011. These two different approaches can demonstrate how national budget problems were solved in these two Baltic States. Considering the world economic crisis, the problem of the national debt management has grown to the big economic value. As the economic situation declines, discussions on the state debt have become more intense. The effective debt management is critical especially during crisis. The high government debt leads to the increase of tax burden, growth of state budget deficit, drop of state consumption level, reduction of public sector salaries and social security payments leading to a negative impact on the state economy, which is already weakened by the crisis and thus is forcing the government to borrow more. The data on the gross national income and the government debt was taken of the crisis period from 1995 to 2011.

To evaluate the change of economic growth in the Baltic States, it is useful to compare national incomes of the period of 1995-2011 (see Table 1). The data on the gross national income and the government debt was taken from the period of 19952011. The data on the gross national income (hereinafter referred to as national income) of Latvia were retrieved from the official website of the Central Statistical Bureau of Latvia (CSB, 2012). The data of Lithuania and Estonia were taken from the Eurostat database (Eurostat, 2013). The national income was taken in actual prices in millions of Euro (Semjonova, 2013). Besides, national incomes is the total net earnings received from the production of goods and services in a country over a period of time, usually one year, and consisting essentially of wages, salaries, rent, profits, and interest. 
Table 1. National income in the Baltics in the period from 2005 to 2013

\begin{tabular}{|c|c|c|c|}
\hline $\begin{array}{c}\text { Lithuania's national } \\
\text { income, billion EUR }\end{array}$ & $\begin{array}{c}\text { Latvia's national } \\
\text { income, billion EUR }\end{array}$ & $\begin{array}{c}\text { Estonia's national } \\
\text { income, billion EUR }\end{array}$ & Year \\
\hline 5.0 & 4.0 & 3.2 & 1995 \\
\hline 6.3 & 4.8 & 3.8 & 1996 \\
\hline 9.0 & 5.1 & 4.7 & 1997 \\
\hline 10.0 & 5.8 & 5.0 & 1998 \\
\hline 10.1 & 6.0 & 5.2 & 1999 \\
\hline 12.5 & 6.3 & 5.7 & 2000 \\
\hline 14.0 & 7.0 & 6.2 & 2001 \\
\hline 15.0 & 7.6 & 7.1 & 2002 \\
\hline 16.0 & 9.2 & 8.0 & 2003 \\
\hline 17.9 & 10.0 & 9.0 & 2004 \\
\hline 21.0 & 12.6 & 10.8 & 2005 \\
\hline 24.0 & 15.3 & 12.5 & 2006 \\
\hline 27.6 & 20.1 & 14.8 & 2007 \\
\hline 31.8 & 22.5 & 15.1 & 2008 \\
\hline 27.1 & 20.0 & 13.6 & 2009 \\
\hline 26.9 & 18.5 & 13.8 & 2010 \\
\hline 29.8 & 20.4 & 15.0 & 2011 \\
\hline & & & \\
\hline
\end{tabular}

Source: Semjonova, N., 2013.

The borrowing policy in Lithuania was to choose private financial institutions, whereas in Latvia it was the International Monetary Fund (IMF). However, the annual interest rates in Lithuania were 4-9\% versus Latvia's interest rates 2-3\%.

The economic and financial policies in Lithuania during that crisis were independent (see Table 2) versus the regulated ones by the IMF in Latvia (see Table 3 ). The outcomes of the independent fiscal policies in Lithuania in the period of 2009-2010 were positive without significant new tax on property and other private property, whereas new taxes on property and motor vehicles were introduced in Latvia. A possible difference of the debt service expenditures in Lithuania from the total national public debt of EUR 17.5 billion was around EUR 800 million in 2017. We can assume that the average annual interest rate is $5 \%$, while the annual interest payments could be around EUR 800 million.

A difference of the debt service expenditures in Lithuania for the same total national public debt EUR 17.5 billion (Lithuanian Government Debt to GDP, 2018) is possible. If the average annual interest rates would be similar to the Latvian ones, i.e., $2.5 \%$, then the annual interest payments could be around EUR 400 million. Therefore, Lithuanian public sector annually pays around EUR 400 million more for the independent financial (and economical) policy. Nevertheless, it is good to 
have an independent public finance policy. Unfortunately, most recent decisions of the Lithuanian government show misunderstandings over the huge cost for the country's independent fiscal policy. There are serious discussions in the Lithuanian parliament and government on the introduction of the overall property tax and private car tax in 2018. However, the Lithuanian government declares a much more optimistic vision: "Investors coming into the Baltic States decide on the location for the head office, factory and service centre. Tax is one of the factors which they base their decision on," said Sapoka (NY Times, 2018).

Meanwhile, Lithuania paid EUR 3.2 billion in 8 years for its right not to introduce the total property tax, motor vehicle tax and other taxes pushed by the IMF, World Bank and European Commission.

However, if the mentioned taxes will be introduced, it will indicate that Lithuania moves to the same point as Latvia in 2009. EUR 3.2 billion in 8 years (or EUR 3.6 billion in 9 years) were overspent and the credibility of public servants could be decreased in the same amount. It is essential to mention that all these calculations are only approximations; however, the main trends are apparent.

Unfortunately, there are very few signs of the continuation of the Lithuanian fiscal policy. Moreover, it could be said that no sufficient financial education has led to the present situation. A similar evaluation of the efficiency and sustainability of the Lithuanian fiscal policy could be applied. Additionally, there are a few critical remarks on the property and wealth taxation promoters. It is impossible to neglect that these taxes come from the Middle Ages when nobody even had idea about value added tax, excise duties, profit tax and even income tax. Of all the mentioned additional taxes, by all means one of the most important indirect tax is the excise tax on petroleum products, electricity, alcohol products and tobacco (Dubauskas 2016).

Thus, the income from person's labour or corresponding labour related activities is taxed about $70 \%$. It is sometimes called the taxation on labour versus the taxation on capital. In this context, the Tax Freedom Day can be mentioned (Roger, J., 2015).

The transparency of 70\% taken from a person's gross income for public interest is still not adequate. Consequently, the example of tax burden as the basis of public finances could be an educational necessity. 
Table 2. Lithuania's GDP and changes of its growth

before and after the crisis in the period of 2005-2013

\begin{tabular}{|c|c|c|}
\hline $\begin{array}{c}\text { Lithuania's GDP at current market } \\
\text { prices, billion LITAS }\end{array}$ & $\begin{array}{c}\text { Lithuania's GDP growth/decline, } \\
\text { in percent }\end{array}$ & Year \\
\hline 76 & 7.8 & 2005 \\
\hline 81.9 & 7.8 & 2006 \\
\hline 90 & 9.8 & 2007 \\
\hline 92.6 & 2.9 & 2008 \\
\hline 78.9 & -14.8 & 2009 \\
\hline 80 & 1.4 & 2010 \\
\hline 84.6 & 5,8 & 2011 \\
\hline 86.7 & 2.5 & 2012 \\
\hline 89.9 & 3.7 & 2013 \\
\hline
\end{tabular}

Source: European Country Risk, 2018 [https://www.euromoneycountryrisk.com/wiki/ Lithuania\#Economic-Overview; https://countryeconomy.com/gdp/lithuania]

Table 3. The changes of Latvia's GDP growth before and after the crisis in the period of 2005-2011

\begin{tabular}{|c|c|c|}
\hline $\begin{array}{l}\text { Latvia's GDP at current } \\
\text { market, billion EURO }\end{array}$ & $\begin{array}{c}\text { Latvia's GDP growth/decline, } \\
\text { in percent }\end{array}$ & Year \\
\hline 2.8 & 4 & 1st quarter 2005 \\
\hline 2.95 & 2 & 2nd quarter 2005 \\
\hline 3.0 & 2.6 & 3rd quarter 2005 \\
\hline 3.1 & 2 & 4th quarter 2005 \\
\hline 3.2 & 4.8 & 1st quarter 2006 \\
\hline 3.3 & 4 & 2nd quarter 2006 \\
\hline 3.5 & 1 & 3rd quarter 2006 \\
\hline 3.54 & 2 & 4th quarter 2006 \\
\hline 3.6 & 2.5 & 1st quarter 2007 \\
\hline 3.7 & 2.1 & 2nd quarter 2007 \\
\hline 3.8 & 2 & 3rd quarter 2007 \\
\hline 3.9 & 2 & 4th quarter 2007 \\
\hline 3.8 & -4 & 1st quarter 2008 \\
\hline 3.7 & -2.5 & 2nd quarter 2008 \\
\hline 3.6 & -2 & 3rd quarter 2008 \\
\hline 3.5 & -3 & 4th quarter 2008 \\
\hline 3.1 & -12.2 & 1st quarter 2009 \\
\hline 2.8 & -8 & 2 nd quarter 2009 \\
\hline 2.7 & -4 & 3rd quarter 2009 \\
\hline
\end{tabular}




\begin{tabular}{|c|c|c|}
\hline 2.65 & -2 & 4th quarter 2009 \\
\hline 2.66 & 0.1 & 1st quarter 2010 \\
\hline 2.67 & 0.3 & 2nd quarter 2010 \\
\hline 2.7 & 1.2 & 3rd quarter 2010 \\
\hline 2.72 & 0.8 & 4th quarter 2010 \\
\hline 2.73 & 0.1 & 1st quarter 2011 \\
\hline
\end{tabular}

Source: CEIS, 2018, [https://www.ceicdata.com/en/indicator/latvia/gdp-growth] and author's calculations

\section{Conclusions}

The critical evaluations of the former "crisis time" of the Lithuanian parliament and government concerning financial policy (especially for expensive state credits supporting the independent financial policy) can also be used for the present-day government. Moreover, such behaviour illustrates inadequate financial decisions because of the high price paid for not introducing the taxes suggested by the IMF during the economic crisis but coming back to the same taxes after a few years.

It is obvious that there is an essential need for a broader financial education and better understanding of public and private finance risks at all levels of public administration managers and parliament members. Moreover, there is an obvious correlation of public and private finance security with future considerations on the monetary policy risks. Eventually, the demand for advanced financial education focusing on transparency in budget and taxation is evident. The clearness of public spending and procurement and budgetary policy are essential issues for every country.

As it has been discussed in a number of European Union countries, financial education and literacy have an existent importance to the general civic education for improving the paradigm of financial knowledge and skills. This is especially true at higher education institutions in connection with the relevant higher education and research programs. Frequently, public finance management and the variety of educational programming interface programs are treated differently. At some schools of higher education, social scientists are still debating whether financial management and, in particular, public finance management can be seen as an important educational and scientific branches of study. In recent decades, the opinion that such a discussion does not lead to direct benefits is becoming increasingly important. Based on public finances, in Central and Eastern Europe called state finances, the model can develop patriots and those intolerant of opaque phenomena. Very often the best citizens' participation in the governance of their country is paying taxes intended for the most important state functions. One of the ways to determine country's aggregated or consolidated taxes paid by natural and legal persons could 
be the tax burden rate. Such data of the Central European statistics authority and national statistical departments or offices often reflect a country's approach to the calculation of the tax burden. Therefore, the understanding of tax burden can encourage each citizen's insistence on the transparency of public servants in their operations and budget planning processes. It also could be an outstanding financial literacy practice for a new generation seeking for their country's sustainability with greater involvement in political activities.

Unfortunately, there are very few marks of the continuity of the Lithuanian fiscal policy. Moreover, it could be said that insufficient financial education has led to the present situation. Analogous evaluations of the efficiency and sustainability of the Lithuanian fiscal policy could be used.

\section{References}

1. AMECO Database, Total Tax Revenue by Country. OECD Economics Department Working Papers, Paris, 2014.

2. Aarma, A., (2012). The Foreign Commercial Banks in the Baltic States: Aspects of the Financial Crisis Internationalization. European Journal of Business and Economics, Vol 5., DOI: http://dx.doi.org/10.12955/ejbe.v5i0.161.

3. Allen, R. and Tommasi, D (eds.) (2011) Managing Government Expenditure: A Reference Book for Transition Countries. Paris: OECD. SIGMA. [Online access]: www1.worldbank.org/ publicsector/pe/oecdpemhandbook.pdf

4. Andersen, T. M., 2010. Fiscal Sustainability in the Wake of the Financial Crisis. Nordic Economic Policy Review 71-110.

5. Brammer, S.; Walker, H. 2017. Sustainable Procurement Practise in the Public Sector: an International Comparative Study. [Online access]

6. http://www.bath.ac.uk/management/ research/pdf/2017-16.pdf

7. Central Statistical Bureau of Latvia (2012). [Online access]: http://www. csb.gov.lv/en/dati/key-indicators-30780.html.

8. Communication from the Commission to the European Parliament, The European Economic and Social Committee and The Committee of the Regions. The EU Council, Brussels, 2014.

9. Davig, T., Leeper, E.M., Walker, T.B., 2011. Inflation and the Fiscal Limit. European Economic Review 55, 31-47.

10. De Haan, J., Sturm, J. E., and B. Volkerink, 'How to Measure the Tax Burden on Labour', the paper presented at the CESifo Conference on Measuring the Tax Burden on Labour and Capital, Venice, July, 2002.

11. Domar, E. (1944). The "Burden of the Debt" and the National Income. The American Economic Review, Volume 34, Issue 4, pp. 798-827.

12. Dubauskas G. Theories of Economics and Finance (Ekonomikos ir finansu teorijos), Vilnius, 2013. http://www.lka.lt/lt/moksline-veikla/leidiniai/leidiniu.../ ekonomika.html 
13. EU Commission Staff Working Document. Economic Review of the Financial Regulation Agenda. Brussels. 2014. Eurostat database. [Online access]: http://epp.eurostat.ec.europa.eu.

14. Eurostat Yearbook, (2016). [Online access]: http://ec.europa.eu/ eurostat/ publications/statistical-books/eurostat-yearbook

15. Lietuvos Respublikos Seimo 1996 m. rugpjūčio 13 d. Lietuvos Respublikos viešujų pirkimų ịstatymas Nr. I-1491 (1996). Valstybės žinios (Nr. 842000), (galiojanti suvestinè redakcija nuo 2017-01-01). [Law on Public Procurement of the Republic of Lithuania: Seimas of the Republic of Lithuania, 1996 August 13 Law No. I-1491 (1996). State Gazette (No. 84-2000), (valid consolidated version as of 01.01.2017)].

16. Lithuania Government Debt to GDP. 2018. [Online access]: https:// tradingeconomics.com/lithuania/government-debt-to-gdp

17. "Lithuania Proposes Income Tax Cuts to Boost Growth", New York Times, 2018, April 17. [Online access] https://www.nytimes.com/reuters/2018/04/17/ business/17reuters-lithuania-tax.html

18. Procurement Management (2017). [Online access]: https://www. deltabid. com/procurement-management/

19. Ministry of Finance of the Republic of Lithuania. (2017). [Online access]: http://finmin.lrv.lt/lt/aktualus-valstybes-finansu-duomenys/valstybes-biudzeto-irsavivaldybiu-biudzetu-vykdymo-duomenys.

20. International Monetary Fund, (2013). World Economic Outlook: Tensions from the Two-Speed Recovery: Unemployment, Commodities, and Capital Flows (No. April, 2013).

21. EU Commission Staff Working Document. Economic Review of the Financial Regulation Agenda. Brussels. 2014.

22. Johansson A, Heady C, Arnold J., Brys B. and Vartia L., 'Tax and Economic Growth'. OECD Economics Department Working Papers, No 620, OECD Publishing, 2008.

23. Jurgutis V. The Basics of Financial Science. (Finansu mokslo pagrindai). Kaunas, 1938, Vilnius, 1995.

24. Madsen Pirie, Think Tank. A Story of the Adam Smith Institute, Biteback Publishing, 2012.

25. OECD, Total Tax Revenue by Country, Economics Department Working Papers, Paris, 2014.

26. Schiavo-Campo, S. and Tommasi, D. (1999) Managing Government Expenditure. Manila: ADB. [Online access]: www.adb.org/documents/manuals/ govt_expenditure/

27. Shah, A. (ed.) (2013) Budgeting and Budgetary Institutions. Washington, DC: World Bank. [Online access]: http://siteresources.worldbank.org/PSGLP/ Resources/BudgetingandBudgetaryInstitutions.pdf

28. Semjonova, N. Application of Government Debt Models for Baltic 
States, RTU, Riga, 2013. [Online access]:

http://aurora.lv/editor/Conference14/vBook/proceeding/pages/EN042

Semjonova/EN042_Semjonova.htm

29. Tax Burden for Typical Workers in the EU. New Direction - The Foundation for European Reform, Brussels, Belgium, 2014.

30. Tax Revenue as Percentage of GDP by Country. The World Bank Report, 2015. [2015-12-02]. Online access: $<$ http://www.apa.org/journals/jwebref. $\mathrm{html}>\mathrm{http}: / /$ data.worldbank.org/indicator/gc.tax.totl.gd.zs?page $=1$

31. Taxation Trends in the European Union, Data for the EU Member States, Iceland and Norway. Eurostat Statistical Book, 2014.

32. The Case for Financial Literacy in Developing Countries. The International Bank for Reconstruction and Development, Washington, DC, 2014. 


\title{
FINANSINIO ŠVIETIMO TRŪKUMAI SIEKIANT TINKAMAI SUPRASTI NACIONALINĘ FISKALINĘ POLITIKĄ
}

\author{
Prof. dr. Gediminas Dubauskas \\ Generolo Jono Žemaičio Lietuvos karo akademija
}

\section{Santrauka}

Viešieji finansai ir pinigu politikos samprata yra svarbi ir universali kiekvienos šalies bendruomenès ugdymo sritis. Šios socialinių mokslų kryptys daro ịtaką šalies raidai ir atskirų piliečių gyvenimui, todèl daugelyje valstybių piliečių ugdymui pasitelkiamos ir viešųjų finansų suvokimo studijos kaip būdas pagrịsti pilietiškumą. Straipsnyje iškeliamos ir nagrinejjamos temos bei mokslinès problemos - viešuju finansų valdymo, kaip svarbios pilietiškumo ugdymo studijų dalies, reikšmingumas - valstybès mokesčių našta, skolos aptarnavimo išlaidos ir reali mokestinè našta. Lyginama dviejų Baltijos šalių Latvijos ir Lietuvos skolinimosi politika nuo du tūkstančiai aštuntų iki du tūkstančiai vienuoliktų metų, tai yra šio amžiaus didžiausios krizès metų, kuomet su ypač brangioms užsienio paskolomis, buvo norima paremti tuometinę nepriklausomą Lietuvos ekonomikos ir finansų politiką, kurios, deja, jau atsisakoma du tūkstančiai aštuonioliktais metais ir grižtama prie praktiškai identiškų Tarptautinio valiutos fondo reikalavimų, kurie buvo pateikti Latvijai. Be abejo kyla pagrịstas klausimas, kodèl nèra viešųjų finansų veiklos tęstinumo. Taip pat aptariamas studentų kariūnų finansinis ugdymas socialinių mokslų krypties programose. Dvidešimt pirmojo amžiaus pradžioje mokesčiu ir viešųjų finansų tematika tampa vis labiau aktuali dẻl nuolatinès pastovių įtampų visuomeneje didinant mokesčius (ir mokestinę naštą) dèl dažnų valstybinių biudžetų deficitu ir viešųų finansų suvokimo tiesioginès naudos bendram pilietiškumo ugdymo plètojimui. Tinkamas skolinimasis ir viešųų pirkimų vykdymas leidžia valstybinei sistemai patenkinti savo poreikius, siekiant strateginių tikslų. Daugelio institucijų problema yra ta,kad pirkimo specialistai, vykdantys viešaji pirkimą, susiduria su įvairiomis problemomis, trukdančiomis sklandžiai vykdyti viešojo sektoriaus viešuosius pirkimus, o dažnai tokios problemos dirbtinai sukuriamos, siekiant asmeninès naudos. Kaip teigia finansų ekspertai, korupcija „suvartoja“ apie vienuolika procentų Lietuvos bendrojo vidaus produkto, o jei šis skaičius mažai pasako, tuomet piniginè išraiška būtų daugiau nei 4 milijardai eurų. Tai yra milžiniški pinigai, net jei šis matavimas labiau pagrịstas ekspertinèmis ịžvalgomis. Didžiausią dalị to, kas galètų būti panaudota visuomeniniam gèriui, galimai pasiima veikejjai korumpuočiausiose Lietuvos institucijose - sveikatos priežiūros sistemoje, Seime, savivaldybėse. Dar galima pridèti ir Lietuvos Respublikos ministerijas - sveikatos apsaugos, žemès ūkio ir daugelị kitų. Panašu, kad tokie neskaidrūs sandoriai galimai nusėda matomai labai korumpuotose viešujų finansų ir ūkio sektoriuose. Todèl nuolatos yra 
labai aktualus ir neišvengiamas viešujų finansų skaidrumo didinant viuomenès finansinį raštingumą, skatinant kuo platesnį viešo administravimo procesų suvokimą. Tai sąlyginai galima pasiekti vis labiau didinant viešų finansų studijas ịvairiuose lygiuose. Kitaip sakant, kuo anksčiau studentai, moksleiviai ir bendrai visi piliečiai gaus finansinių žinių, tuo geresnių rezultatų pasieksime. Ypatingai atskleidžiant bei netoleruojant neskaidrius viešus pirkimus, dažnai akyvaizdų interesų konfliktą ir bendrą didelies dalies piliečiu nusivilimą dabartinèmis šalies realijomis. Galima dar kartą apgailestauti, kad atsakingos viešo sektoriaus institucijos, kurios beveik nuolatos vykdo permanentines reformas, bet tik ne finansinio raštingumo srityje, ịtraukiant $\mathfrak{i}$ visų lygių formaliojo ugdymo programas tokias finansinio raštingumo programas, kad sudaryti galimybes besimokantiems ir pedagogams tobulinti bei palaikyti kvalifikaciją finansinio ir mokesčių administravimo raštingumo srityje. Dabartinei valdančiai Seimo daugumai ir vyriausybei taip pat gali būti taikomi tokie pat kritiški Lietuvos parlamento ir vyriausybès "krizès laiko" vertinimai, dél nuolatinio grịžimo prie mokestinès naštos didinimo klausimų ir naujų mokesčiu ịvedinejjimu. Tie mokesčiai buvo ịvesti Latvijoje krizès metais, ir todèl TVF skolino latviams kelis kartus mažesnėmis palūkanomis. Taip per aštuonerius metus Lietuva sumokèjo tris milijardus ir du šimtus milijonų eurų daugiau palūkanų, sąlyginai sakant „už teisę netaikyti“ visuotinio turto mokesčio ir visuotino automobilio mokesčio kaip beje ir kitų mokesčių, kuriuos Tarptautinis valiutos fondas, Pasaulio bankas, Europos Komisija bei panašios institucijos nuolat siūlo Lietuvai. Panašu, kad dabar, tai yra du tūkstančiai aštuonioliktais metais, ir Lietuvoje bus ịvesti tokie nauji mokesčiai, kurie buvo pritaikyti Latvijoje, nors Lietuvos skolinimasis buvo daug brangesnis, kaip jau minèta, būtent dèl tuometinio noro išlaikyti nepriklausomą šalies finansų politiką, ir todèl palūkanoms yra sumokama šimtais milijonų eurų daugiau nei mokejo ir moka Latvija. Tai be abejo susiję ir su daugumos viešųų tarnautojų šalies finansinès politikos suvokimu ir jos tęstinumo užtikrinimu.

Raktiniai žodžiai: valdymas, viešieji finansai, biudžetas, mokesčiai, tvarumas 


\section{AUTORIAUS LYDRAŠTIS}

Autoriaus vardas, pavardė: Gediminas Dubauskas

Mokslo laipsnis ir vardas: daktaras, profesorius

Darbo vieta ir pareigos: Generolo Jono Žemaičio Lietuvos karo akademija, Vadybos katedros profesorius

Autoriaus mokslinių interesų sritys: vadyba, finansai, ekonomika, eduko$\log$ ija

Telefonas ir el. pašto adresas: (8 6) 727 9858;

gediminas.dubauskas@1ka.lt

\section{AUTHOR'S COVER LETTER}

Author's name and surname: Gediminas Dubauskas

Academic degree and name: Professor, Doctor

Workplace and position: General Jonas Žemaitis Military Academy of Lithuania, Department of Management

Author's research interests: management, finance, economics, education

Telephone and e-mail address: +37067279 858,

gediminas.dubauskas@lka.lt 